University of Rhode Island

DigitalCommons@URI

The Rhode Island Current Conditions Index

Economics

$12-1-2020$

\title{
Rhode Island Current Conditions Index - December 2020
}

Leonard Lardaro

University of Rhode Island, lardaro@uri.edu

Follow this and additional works at: https://digitalcommons.uri.edu/ricci

Part of the Econometrics Commons

Terms of Use

All rights reserved under copyright.

\section{Recommended Citation}

Lardaro, Leonard, "Rhode Island Current Conditions Index -- December 2020" (2020). The Rhode Island Current Conditions Index. Paper 215.

https://digitalcommons.uri.edu/ricci/215

This Newsletter is brought to you for free and open access by the Economics at DigitalCommons@URI. It has been accepted for inclusion in The Rhode Island Current Conditions Index by an authorized administrator of DigitalCommons@URI.For more information, please contact digitalcommons-group@uri.edu. 


\title{
CURRENT CONDITIONS
INDEX
}

\section{LEONARD LARDARO, URI}

\author{
Available Online: http:/ / www.Ilardaro.com/current.htm \\ Twitter: @ladardo
}

VOL XXVIII

NUMBER 1

DEC 2020

Rhode Island's economic performance at the end of 2020 was largely the same as it has been throughout the pandemic: Severe contraction compared to a year ago, sprinkled with a few glimmers of light for the most recent few months. Was this year's performance merely a reflection of what is happening nationally or is there something else at work? While we, like everyone else were literally dragged into shutting large parts of our state's economy down, where we find ourselves now must also be judged relative to how well our state's economy was performing prior to the pandemic

As I have noted countless times over the last couple of years, Rhode Island's economy has remained largely stuck at its 2016 level (based on real GDP). Resident employment, even before the pandemic hit, remained below its level of December 2006 - more than a decade earlier! The statistical deceivers in our state hid behind a very low jobless rate, but that was a byproduct of mediocre growth in resident employment coupled with a decade long decline in our state's Labor Force. And, while Rhode Island's economy is clearly FILO, we were spared the FI portion this time (as everyone fell sharply at the same time), but since our elected officials (not to be confused with leaders) have effectively wasted

\begin{tabular}{|r|r|r|r|r|r|} 
& Feb-20 & Dec-20 & Chg & \% Chg & \\
\hline Government Employment & 66.0 & 62.5 & -3.5 & -5.3 & \\
Consumer Sentiment & 100.6 & 78.5 & -22.1 & -22.0 & \\
\hline Single-Unit Permits & 1127.2 & 1180.3 & 53.1 & 4.7 & $\mathrm{Y}$ \\
\hline Retail Sales & 17.7 & 18.4 & 0.6 & 3.6 & $\mathrm{Y}$ \\
\hline Employment Service Jobs & 9.3 & 7.5 & -1.8 & -19.3 & \\
\hline Priv Serv Producing Jobs & 446.9 & 399.8 & -47.1 & -10.5 & \\
\hline Manufacturing Employment & 39.4 & 38.8 & -0.6 & -1.5 & \\
\hline Manufacturing Wage & 37.5 & 37.4 & -0.1 & -0.3 & \\
\hline Manufacturing Wage & 19.6 & 21.1 & 1.5 & 7.7 & $\mathrm{Y}$ \\
\hline Labor Force & 558.5 & 542.4 & -16.1 & -2.9 & \\
\hline New Claims for UI & 26.5 & 190.8 & 164.3 & 621.2 & \\
\hline Benefit Exhaustions & 6.7 & 31.1 & 24.4 & 364.5 & \\
\hline Unemployment Rate & 3.4 & 8.1 & 4.7 & 138.2 & \\
\hline Payroll Employment & $\mathbf{5 0 8 . 4}$ & 461.9 & -46.5 & -9.1 & \\
\hline Resident Employment & $\mathbf{5 3 9 . 8}$ & 498.4 & -41.4 & -7.7 &
\end{tabular}

this crisis, as they did in 2008, we have failed to reinvent ourselves to make our state's economy more competitive and linked to national growth than it has been in a while. In other words, the LO remains. None of our elected officials have yet to define specifically what Rhode Island's economic niche is and how to energize and possibly redefine our engines of growth. This would certainly be an opportune time to do so, as our state continues to rank at or near the bottom for all business climate surveys. Perhaps there should be a new show that replaces Hawaii Five-0: Rhode Island 50. In the future, we must reinvent our state's economy and business climate. Sadly, this state is run exactly the same it has been for forty years, even though the economic world has changed. For this reason, I continue to believe it will take three to five years for Rhode Island to return to where it was pre-pandemic, and that wasn't all that great!

This month, I am doing something a bit different. The table above

\begin{tabular}{|l|l|l|l|l|l|}
\hline & & Jan & Feb & Mar & Apr \\
\cline { 2 - 6 } & 2019 & $58 \downarrow$ & $50 \uparrow$ & 58 & $50 \downarrow$ \\
\cline { 2 - 6 } & 2020 & 75 & 75 & 55 & \\
\end{tabular}

Gopyright ( 2019,2020 Leonard Lardaro, Ph.D. All rights reserved.

is not for year-over-year comparisons of the CCI indicators, but a contrast of February with December of 2020. The depth of the decline in our state's economy is shocking. Only three CCI indicators have improved relative to February, the same three that have done so for months now. Look at employment (bottom): Both measures have decline by over 40,000 since February! It seems we don't do terribly well in good times, but manage to fall precipitously when things get bad, same as 2008 .

There might be some good news on the horizon. First, we will soon get the revised labor market data for 2020. It might (key word) show that the declines were not as bad as what we are seeing now. Second, the monthly based CCI again reached 58, an expansion value, for the fourth time in the last five months. So maybe we are in or moving towards the early stages of crawling out of the depth of our declines. If so, where are we headed? More slow and lagging growth with our elected officials continuing

\begin{tabular}{|l|r|}
\hline CCI Indicators - Monthly\% Change \\
\hline Government Employment & -2.0 \\
\hline US Consumer Sentiment & $2.2 \mathrm{Y}$ \\
\hline Single-Unit Permits & $12.6 \mathrm{Y}$ \\
\hline Retail Sales & $0.1 \mathrm{Y}$ \\
\hline Employment Services Jobs & -7.0 \\
\hline Priv. Serv-Prod Employment & -1.6 \\
\hline Total Manufacturing Hours & $1.1 \mathrm{Y}$ \\
\hline Manufacturing Wage & -0.7 \\
\hline Labor Force & $0.1 \mathrm{Y}$ \\
\hline Benefit Exhaustions & $-33.7 \mathrm{Y}$ \\
\hline New Claims & $-7.8 \mathrm{Y}$ \\
\hline Unemployment Rate (change) & 0.8 \\
\hline \multicolumn{2}{|c|}{ Y = Improved Value } \\
\hline
\end{tabular}

to hide behind misleading statistics, telling us always to focus on the positive. That's not leadership, it's denial, a major reason why our economy has continued to do so badly. Let me summarize this state of affairs with two words: Endogenous Mediocrity: Rhode Island's economic mediocrity is a logical and predictable outcome of the way things are and are not done here.

\begin{tabular}{|c|c|c|c|c|c|c|c|}
\hline $\mathbf{L}$ & BOR & DRCE & DE & 2020 & $\mathrm{Pe}$ & ak (1) & 2007) \\
\hline Part & ipatic & Rate & & $5 \%$ & & 68.6 & \\
\hline Emp & byme & Rate & & $.4 \%$ & & 65.4 & \\
\hline 100 & $\mathrm{CClC}$ & er the & ast 13 & onths & & & \\
\hline $\begin{array}{l}90 \\
80\end{array}$ & & & & & DLT & $\begin{array}{l}\text { DEC } 2 \\
\text { SA,Y/Y }\end{array}$ & 20 \\
\hline \begin{tabular}{|l|}
70 \\
60
\end{tabular} & & & & & & & \\
\hline $\begin{array}{l}60 \\
50\end{array}$ & & NNEX & Rat & & Gair & & 200 \\
\hline $\begin{array}{l}40 \\
30\end{array}$ & & 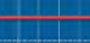 & 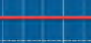 & 4 & & & \\
\hline 30 & & & 15 & & Los: & &, 000 \\
\hline $2019 \mathrm{M}$ & Mo2 2 & MO4 2020N & $\frac{1}{2020 M 08}$ & $\frac{1}{M 10} 2020 \mathrm{M}$ & Vet C & $(45$ & 800 \\
\hline May & Jun & Jul & Aug & Sep & Oct & Nov & Dec \\
\hline $50 \downarrow$ & $58 \downarrow$ & $75 \downarrow$ & 67 & $50 \downarrow$ & $75 \downarrow$ & $58 \downarrow$ & $83 \downarrow$ \\
\hline & $\uparrow$ & 25 & 25 & 25 & 17 & 2 & \\
\hline
\end{tabular}

